\title{
INTERACTION BETWEEN APPARENT AND IMPLIED AUTHORITY IN THE IMPLEMENTATION OF SUSTAINABLE BUSINESS RELATIOHSIPS
}

\author{
Vaidas JURKEVIČIUS (1) 1*, Raimonda BUBLIENE்(102 \\ ${ }^{1}$ Institute of Private Law, Law School, Mykolas Romeris University, \\ Ateities g. 20, LT-08303 Vilnius, Lithuania \\ ${ }^{2}$ Department of Law, Faculty of Business Management, Vilnius Gediminas Technical University, \\ Sauletekio al. 11, LT-10223 Vilnius, Lithuania
}

Received 27 February 2021; accepted 01 April 2021

\begin{abstract}
Purpose - to reveal the problems of apparent and implied authority in the context of sustainable business relationships.

Research methodology - the research is conducted from a comparative perspective, explaining the problems of apparent and implied authority in selected jurisdictions.

Findings - authors conclude that apparent authority is the exclusive remedy available only where a link has been established between the circumstances of the principal and the reasonable belief of the third party. Implied authority cannot be equated with apparent authority, although case law often does not distinguish between these two categories.

Research limitations - due to limited scope, this article does not address the ratification of unauthorised agent's actions and the liability of falsus procurator.

Practical implications - the research reveals that implied authority derives from the factual circumstances in which the agent acts and must be regarded as part of the actual authority, which presupposes that, unlike in the case of apparent authority, the implied representation does not qualify as one of the cases of unauthorised agency.

Originality/Value - the significance of this study is linked to the development of reasonable rules for the application of apparent and implied authority in order to safeguard the legitimate interests of all persons involved in this complex relationship.
\end{abstract}

Keywords: apparent authority, implied authority, agent, unauthorised agency, sustainable business.

JEL Classification: K12, K20.

Conference topic: Business Processes: Development, Digitalization, Social Responsibility.

\section{Introduction}

If we observe research that analyses how large firms adopt and integrate sustainability, a strong understanding emerges that sustainability has and will have a significant impact on firm strategies and operations (Dyllick \& Muff, 2016). Over the last ten years, research on sustainable innovation has expanded rapidly to better understand how new technologies and social practices enable society to become more sustainable (Boons \& Lüdeke-Freund, 2013).

The possibility to participate in business relations through an agent is a guarantee of the implementation of a person's right to freedom of economic activity and initiative (Smits, 2007). That is why the legal regulation of agency relations is essentially indispensable in every country.

According to the general principle of agency in civil law, legal actions performed by one person (agent) on behalf of another person (principal) directly create, change and revoke the rights and obligations of the principal. These consequences do not arise for the principal, if legally significant actions are performed on his behalf by a person who exceeds the rights granted to him or has not even been granted such rights at all. Nevertheless, in principle, all modern legal systems recognize that even if a person does not express his will to be represented or an agent deviates from the instructions given to him, the usual legal consequences of agency may arise (Jurkevičius \& Bublienè, 2017). Such

*E-mail: vaidas.jurkevicius@mruni.eu

(C) 2021 Authors. Published by Vilnius Gediminas Technical University. This is an open-access article distributed under the terms of the Creative Commons Attribution (http://creativecommons.org/licenses/by/4.0/) License, which permits unrestricted use, distribution, and reproduction in any medium, provided the original author and source are credited. 
exceptions to the general legal consequences of unauthorized agency are necessary to ensure the stability of contracts concluded through agents and to protect the interests of bona fide participants in civil circulation. The most common case is when a principal may be bound by contracts entered into on his behalf or by other legal actions performed by an unauthorized agent, i.e., apparent authority.

Historically, apparent authority is described as one of the main problems of the institute of agency (Stoljar, 1961). These are cases where, by considering certain circumstances under which the principal is generally held liable, an impression is created that the actions with legal consequences are carried out by an authorized agent. Apparent authority is primarily intended to protect the interests of a third party who honestly and reasonably believes that a legal relationship of agency has been established (Jurkevičius \& Pokhodun, 2018). In turn, the principal, who did not in fact grant another person the right to act on his behalf, usually seeks to deny the fact of apparent authority and to transfer the liability to the agent who performed the unauthorized actions. The latter is also usually not interested in the application of apparent authority, since in this case he may be obliged to cover the losses incurred by the principal as a result of the apparent contract. To avoid this, the agent attempts to prove that specific facts presuppose that a relationship of actual (usually implied) authority has been established rather than apparent one, and therefore the principal is liable to the third party. Given that the parties to the agency relationship seek fundamentally different legal consequences, it is important to ascertain how apparent authority should be regulated and interpreted in case law in order to reconcile the conflicting interests of the parties and to prevent abuse of authority. In foreign countries (especially France and countries with a common-law tradition), there is a tendency for the principal to be held liable for the actions of the unauthorized agent under the doctrine of apparent authority, even if he had nothing to do with the conviction of the third party as to the reality of the powers granted to the agent. Since apparent authority is an exception to the principle of autonomy of will, the liability of the principal should not be absolute and applies in almost every case of apparent authority.

One of the main problems with apparent authority arises from the disclosure of its correlation with implied authority, where the agent is not deemed to have exceeded the rights granted to him or to have acted without being granted such rights. Implied authority is considered to be part of actual authority and has fundamentally different legal consequences from those of apparent authority. That is why these two types of authority should be separated from each other, by revealing the peculiarities of each of them in a comparative aspect. It should be noted that both apparent authority and implied authority are particularly important for ensuring sustainable business, as they make it possible to avoid formalities in the establishment and implementation of representation relationships.

As the purpose of this article is to explain how the concept of apparent agency has been formed in different legal systems and what its features are, and to analyse how apparent authority can be distinguished from other similar types of representation, namely implied authority, the most important method of data analysis in this work is comparative. This article focuses on general issues related to apparent authority and implied authority, by choosing the Republic of Lithuania as the primary jurisdiction in whose legal system both types of the said authority are recognized. The case of Lithuania is assessed in the article through the prism of foreign countries and soft law instruments. Taking into account the legal context of this research, this article uses specific methods of legal interpretation (e.g., systemic, historical, teleological).

\section{The concept of apparent authority and implied authority}

What comparative law experts now call apparent authority (it should be noted that the concept of ostensible authority is used in countries with a common-law tradition) has developed in many national legal systems by way of extra legem, i.e., through case law and the legal doctrine. As early as in the 18th century, when deciding on the validity of contracts concluded by unauthorized persons, the courts of different countries began to consider whether the circumstances as a whole did not lead a third party to reasonably believe that he has been negotiating with an agent holding the necessary rights. It has been recognized that if, in such cases, the principal is not bound by legal actions performed on his behalf, then agency as a legal instrument of economic circulation may lose its practical significance: in the absence of certainty as to the legal consequences of the actions performed through an agent, third parties will avoid concluding contracts with agents (Saintier, 2009). The case law which has been evolving in this direction has also led to the development of a theoretical basis in legal doctrine, which would enable to explain why in certain cases it is necessary to protect the interests of a bona fide third party, regardless of the will of the principal. In view of the interpretations formed in jurisprudence, the concept of apparent authority has also been transposed to positive law in some legal systems.

Although different notions of apparent authority prevail in different legal systems, they also have many features in common. In all the jurisdictions, which recognize apparent authority, it is considered an exception to the general rule of unauthorized agency according to which the actions taken by one person without or in excess of authority do not create rights and obligations for another person. In other words, apparent authority is a way of legitimizing the unauthorized actions of an agent, which seeks in particular to protect the interests of third parties who honestly and 
reasonably believe that the agent has been duly authorized. With that in mind, the courts, legal doctrine, and in some cases positive law, recognize that a relationship of agency can be established not only when the agent is given express or implied authority, but also when the agent acts under conditions of apparent authority.

The application of apparent authority means a breach of the principle of the autonomy of the will, since a person, even without granting powers, is bound by contracts concluded on his behalf or by other acts of legal significance. This exception is linked to the protection of the interests of third parties and is justified by the circumstances of the principal's behaviour. If the principal's statements or specific actions convince the contractor that he has authorized another person to act on his behalf, or that such third party's belief was determined by other circumstances relating to the principal, the fact that the agent acted without authority can no longer be used as grounds later on.

Given that, in the case of apparent authority, the true will of the principal is not expressed or is distorted, this type of authority is often also described as a certain form of liability. Although, in a general sense, the term liability may be used in the context of this legal relationship, given that the principal is held liable to a third party for the actions performed by the unauthorized agent, apparent authority does not in all cases imply the stricto sensu application of civil liability. Whether apparent authority can be directly linked to the institute of civil liability depends on its prevailing concept in a particular legal system. Where a contract concluded by an unauthorized agent is deemed to be valid and a third party may make any claims relating to the contract against the principal, apparent authority shall not be treated as civil liability. In these legal systems, the confirmation of apparent authority first of all obliges the principal to perform his obligation in kind, and only failure to perform the said obligation shall grant the third party the right to claim civil liability. Meanwhile, in jurisdictions where it is not recognized that the contract in question has been concluded and the third party can defend its rights only through the institute of indemnification, apparent authority can be understood as the application of civil liability in terms of the arising legal consequences. It is interesting to note that although these legal systems do not consider contracts concluded between a third party and the principal to be valid, the principal's liability is based precisely on the rules of contractual liability and the third party is usually compensated for any positive losses.

Essentially, in all cases, agency relationship visibility (image) is the basis for the interpretation of the doctrine of apparent authority. A third party believes that he is entering into a contract with a duly authorized agent, when in fact the opposite is true: the agent, acting on behalf of the principal, does not have the necessary powers to do so. That is why apparent authority is visually described as a situation that differs from reality, but is perceived by the third party as reality (Samoy, 2009). Apparent authority confers a condition of validity to such a misconception and a legal protection for those who believed in what is not real while acting in good faith (Busch \& Macgregor, 2009).

The doctrine states that the term apparent authority is not accurate, since the word "apparent" suggests that no legal relationship of agency has been established between the parties. This is not true, as apparent authority usually has the same legal consequences as those arising from the actions of a duly authorized agent. It is therefore advisable, in the case of this type of authority, to focus on apparent authorization (Zimmermann, 2009), bearing in mind that, although the granting of rights is conceivable, the consequence arising therefrom - the legal relationship between the principal and the third party - is real. In France and England, the notion of apparent authority is also criticized, arguing that the use of the term's "powers" and "authorization" in this context is only possible in a figurative sense, since no powers of attorney are issued to the agent in practice, nor is there any mandate agreement concluded between the parties (Saintier, 2009). That is why apparent authority is also called quasi-authority (Verhagen, 1995). Furthermore, since apparent authority is based on the relevant legal rules establishing the rights and obligations of parties instead of an agreement made between the principal and the agent or a unilateral act of expression of the principal's will, it is also understood as one of the forms of statutory agency (Von Bar et al., 2009). Only through law does apparent authority, as the illusion of agency, become a reality (Munday, 2010).

Generally, the doctrine states that the principal is bound by the actions of the agent when the latter acts with actual or apparent authority (Meier, 2007). It should however be noted that, in legal systems in which the legal consequences of apparent authority are no different or very similar to those in other cases of agency, apparent authority is not put in contrast to actual authority, even if it is pointed out that they are fundamentally different in nature (Verhagen, 1995). In turn, actual authority is divided into express authority and implied authority (Beatson, 2002). Express authority is considered when the principal indicates orally or in writing (for example, via a written power of attorney or mandate) what actions of legal significance the agent may perform. Whereas implied authority arises from the principal's behaviour or the circumstances under which the agent acts. Implied authority, as part of actual authority, is unavoidable in the business sphere since it is not possible to list precisely all the actions that the agent is entitled to perform in a written power of attorney, mandate, or other agreement concluded between the principal and the agent. Therefore, implied authority typically always supplements express authority, particularly the scope thereof. If, for example, a car owner (principal) requests to drive his car from London to Edinburgh, his driver (agent) is likely to have an implied right to purchase fuel, and thus the principal will be obliged to pay the fuel seller (third party) (Elliott \& Quinn, 2005). And it will only very rarely be considered that the agent does not have any implied authority, for example, in cases where the principal defines the rights of the agent in great detail (Seavey, 1964). 
The fact that the rights conferred on an agent, as well as the fact of agency itself, may be implied is enshrined in all international legal instruments, with the exception of the European Contract Law. Article 3:201(1) of PECL (Lando \& Beale, 2000) states that the agent's rights to act may be express or may be implied depending on the circumstances. A somewhat more laconic agency is regulated by the DCFR (Von Bar et al., 2009), Article II. - 6:103(2) of which states that both express and implied authority may be granted to an agent. A similar position is reflected in Article 2.2.2(1) of the UNIDROIT Principles (UNIDROIT Principles of International Commercial Contracts, 2016) and Article 9(1) of the Geneva Convention (Geneva Convention on Agency in the International Sale of Goods, 1983). Implied authority as a legal basis for the actions of an agent is also enshrined in the legal acts of many countries, such as France, Germany, Austria, the Netherlands, Estonia, Poland (Von Bar et al., 2009), Russia and others.

\section{Differences and similarities between apparent and implied authority}

Situations of apparent authority and implied authority often overlap and it is not always easy to identify the nature of the powers an agent holds in a particular case (Verhagen, 1995). Although theoretically their delimitation does not pose any major problems, it is noted that in practice the line between apparent authority and implied authority is so blurred that the way in which the relation of a dispute is classified will depend solely on subjective criteria (Kotz \& Flessner, 1997). It should be noted that, from a historical perspective, prior to the formation of the doctrine of apparent authority, a third party could defend its interests solely on the basis of implied authority: i.e., if the principal filed a claim for annulment of a contract concluded by an agent in excess of his rights, the third party could defend its interests by claiming that the principal had granted the agent broader authority (Levinthal, 1923).

The main difference between these types of authority is that the implied rights of an agent are part of actual authority and therefore, in these cases, it is considered that a legal relationship of unauthorized agency has not been established between the parties. Whereas in the case of apparent authority it is always considered that a person acts without or in excess of authority. In other words, unauthorized agency is a precondition for the doctrine of apparent authority, which legitimizes the unauthorized agent's actions in relations with third parties.

In the case of implied authority, the principle of autonomy of the will of the principal is not considered to be infringed, since the implied rights of the agent derive from the implied intentions of the principal. Whereas in the case of apparent authority the agent concludes contracts that distort or do not express the will of the principal. If circumstances other than those relating to the principal allow the third party to reasonably believe that the agent operating under apparent authority has been duly authorized, a legal relationship between the principal and the third party would not be established.

In the case of implied authority, the agent's conferred rights are not overt - even though they are not directly stated by the principal, they are an integral part of the mandate of the agent or actually arise from specific factual circumstances. Consequently, a contract concluded under implied authority may not be waived, whereas such a possibility exists in the case of apparent authority (Busch, 2009).

The applicability of implied authority is questionable when there is no legal relationship between the agent and the principal, i.e., when facing the actions of an unauthorized person. It is clear that, if the principal does not authorize a particular person to act on his behalf, only the application of apparent authority may be called into question, even though externally it may appear that the dishonest agent has implied authority after assuming a certain position.

In most cases, the problem of distinction between apparent authority and implied authority arises when the agent is authorized to act on behalf of the principal. In practice, it is not easy to determine whether specific actions taken by the agent are inseparable from the specific powers conferred on the agent, i.e., the agent may be considered to have acted under implied authority conditions, or it must still be established that the agent has exceeded his powers and a decision must be made regarding the application of the rules of apparent authority. When assessing the scope of the agent's rights, it is important to consider both how the third party perceived the agent's authority, and how it can be assessed in the context of the relationship between the principal and the agent. If the agent assumes a position in which a person is generally considered to have certain rights, then implied authority must be established, unless the principal expressly states that the agent is not granted specific rights (DeMott, 2006). In all cases, the principal has the right to reduce the scope of implied authority granted to the agent, however it is necessary to inform third parties thereof. Otherwise, even though the agent will act without being granted the necessary authority, the third party will have good reason to believe that the relevant rights have been granted to the agent, which would presuppose apparent authority (Munday, 2010). It should be noted that in legal systems where it is necessary to prove the condition that the third party has believed that the agent was duly authorized due to the actual actions of the principal, the mere fact that the principal had appointed the agent to a particular position may be considered insufficient to rely on apparent authority (Busch \& Macgregor, 2007). In addition, if the principal has imposed certain limitations on the rights of the agent, anything that does not cover them may be considered to be implied rights of the agent (Lando \& Beale, 2000).

It is irrelevant to the third party whether the agent acted with implied or apparent authority, since in both cases they have essentially the same legal consequences, i.e., the principal is bound by the actions taken by the agent. Whereas 
in the context of internal relationship of agency this has essential significance. In the case of implied authority, the agent is deemed to be acting with actual authority and is therefore not liable to the principal, whereas in the case of apparent authority, as a general rule, the principal acquires the right to claim damages from the agent who carried out the unauthorized actions. In this context, implied authority is more in line with the interests of the agent and apparent authority - to those of the principal.

In some parts of the doctrine, the distinction between apparent and implied authority is drawn precisely from the perspective of internal and external relationship of agency, arguing that apparent authority should be linked to the relationship between the principal and the third party, whereas implied authority is a feature of the internal relationship between the agent and the principal (Verhagen, 1995). Such interpretation may presuppose a misconception that apparent authority and implied authority are seemingly two different sides of the same phenomenon. Although it is often hard to draw a line between apparent authority and implied authority, however, it should never be the case where different representation grounds are established in internal and external relationship of agency due to the same actions of the agent. These two types of authority do not coexist in the case of a specific situation: establishment of apparent authority in a dispute between a third party and the principal will not lead to a situation in which the agent will be deemed to have acted under implied authority conditions in terms of internal relationship of agency, and, conversely, if implied authority is established in an internal relationship, then a relationship between the principal and a third party will not be established on the grounds of apparent authority. When apparent or implied authority is proven, it leads to legal consequences in both internal and external legal relationship of agency. For example, if during a dispute between a bank and a customer over whether a bank employee had the right to grant a loan of an appropriate amount it is established that this right is integral to the agent's express authority, the bank will not be able to deny this implied right and claim damages from the employee. Thus, the same rules for determining the content of authority must be applied when assessing specific behaviour of the agent from the perspective of both an internal and external relationship (Stoljar, 1961). However, this does not mean that, in the general context of the content of the agent's rights, apparent authority cannot supplement implied authority: certain actions of the agent may be found to be performed within the limits of the agent's implied rights, while others may be classified as part of apparent rights. For example, a seller's agent will normally be considered to have the right to accept claims about the quality of the goods (implied authority), however it is also established that the agent cannot enter into contracts for the wholesale supply of goods. If the agent still performs these actions, a third party will be able to rely on apparent authority after proving the conditions for the application thereof.

It should be noted that in cases of implied and apparent authority, the burden of proof is differently divided between the parties. Apparent authority is not presumed - the conditions for its application must be proved by a bona fide third party (Vogenauer \& Kleinheisterkamp, 2009). Since apparent authority is linked to a third party's reasonable belief in the authority of the agent, the third party has to specify what gave rise to this conviction. It should also be noted that in legal systems where apparent authority is understood not only as a means of defending the infringed rights of the third party, but also those of the principal, the latter has to justify the application of apparent authority in order to rely on the legal consequences thereof (Vogenauer \& Kleinheisterkamp, 2009). It is also noted in the case law of the Lithuanian courts that the circumstances in which there were serious grounds to believe that a contract has been concluded with an authorized agent of another person must be proved by the party who relies on these circumstances (Judgment of the Supreme Court of Lithuania of 2012 March 20, civil case no. 3K-3-102/2012). Whereas in the case of implied authority there can be some presumption of existence of the agent's authority. If the principal claims that the agent did not have the necessary powers during the conclusion of a contract, it is sufficient for the third party to specify certain factual circumstances of the agent's behaviour which will normally indicate the implied rights of the agent (for example, to specify that the lawyer has the right to conclude a settlement agreement, the seller to sell goods, etc.) (Beale et al., 2010). The principal shall have the burden to prove that the agent did not have the appropriate powers in a particular case, in the light of the circumstances specified by the third party. If the principal denies the existence of implied authority by admissible means of proof (for example, proves that it has in fact prohibited the agent from carrying out certain actions), then the third party may rely on the doctrine of applied authority, but, as mentioned before, it shall bear the burden of proving all the conditions necessary in a particular jurisdiction for the application of this remedy.

It should be noted that the line between apparent and implied authority is particularly blurred in Germany. In the legal doctrine of this country, Duldungsvollmacht, which, as mentioned previously, is described as one of the types of apparent authority, is also regarded as part of implied authority (Schmidt-Kessel \& Baide, 2009). This conclusion can be drawn from the fact that in English sources Duldungsvollmacht is referred to as a type of constructive authority. A German equivalent of this English term is not provided, but it should be translated into Lithuanian as implied authority. However, it is considered that the content of Duldungsvollmacht is not identical to the traditional concept of implied authority. As it was explained, in the case of implied authority, the agent is considered to be acting with actual authority arising from the circumstances under which the agent operates. Whereas in the case of Duldungsvollmacht there is no factual basis for a broad interpretation of the scope of authority, since the agent actually exceeds the rights granted to him or acts without even being granted such rights. That is why it is not appropriate to treat 
Duldungsvollmach as one of the cases of implied authority. It is also questionable whether this basis of an agency relationship can in all cases be classified as apparent authority. Since tolerance of the actions of an unauthorized agent on the part of the principal may often be unknown to a third party, it may fail to prove the basic condition for the application of apparent authority, namely the behaviour of the principal, which gives the third party the impression that the agent's authority is genuine. In this context, it is worth noting the experience of Austria, which has transposed both Anscheinsvollmacht and Duldungsvollmach into its legal system in interpreting these categories of authority. In Austria, Duldungsvollmach has a dual meaning and is treated both as a type of apparent authority and as one of the means of verifying the actions of an unauthorized agent (Von Bar et al., 2009). This doctrinal position is to be welcomed, since in cases where the principal tolerates the behaviour of his agent but the factual circumstances do not meet the conditions for the application of apparent authority, such omission may be understood as consent regarding the agent's unauthorized actions. Furthermore, since the principal is generally aware of the person acting on his behalf before the latter takes specific action, such non-interference could also be regarded as a form of implied authority (Kotz \& Flessner, 1997).

In contrast to Duldungsvollmach, other cases of constructive authority distinguished in the German legal system should be classified in a completely different way, namely: 1) when a third party enters into a contract with an agent without knowing that the principal has revoked the powers of the agent or they have expired on other grounds; 2) when the ordinary powers of a retail seller or warehouse worker are restricted; 3) when a third party acts by relying on information on the rights of a procurator specified in the trade register, which does not correspond to reality. Since, in these situations, it is considered that the agent does not have or exceeds the powers conferred to him, it should not be a question of implied authority but of apparent authority, given how it is understood in other legal systems.

It is also important to note that, in addition to apparent and implied authority, there is another type of authority in the doctrine, which is usual authority. Essentially, usual authority could be classified as implied authority, i.e., which is specific to a particular position of the agent or which is treated as part of apparent authority if the implied rights of the agent are restricted in the internal relationship of agency (Verhagen, 1995). The emergence of the legal relationship of this type of agency was determined by the situation where an unauthorized person acts under the conditions of undisclosed agency. Since in this case the third party is not aware that one person is acting in the interests of another, the undisclosed principal cannot be held liable under the rules of apparent authority due to the fact that the other contractual party reasonably believed that the agent's actions were lawful. This specific category of agency has emerged in countries with a common-law tradition to justify the application of liability of an undisclosed principal. It is argued that in the case of not only disclosed but also undisclosed authority, the principal must be held liable for all actions taken on his behalf, which are customary for the specific position of the agent, regardless of the breach of limits imposed by the internal relationship of agency (Reynolds et al., 2010). It should be noted that in continental law countries the concept of usual authority is not known, since, as mentioned above, the doctrine of apparent authority may also be invoked in the case of the legal relationship of indirect agency.

\section{The problem of demarcation of implied authority and apparent authority in Lithuanian civil law}

Demarcation of implied authority and apparent authority is particularly complicated in Lithuanian civil law. In the doctrine and the case law based on it, the concept of apparent authority has long been interpreted by linking it to implied authority. The problem arises from the fact that Article 2.133(2) of the Civil Code (CC) of the Republic of Lithuania (2000) covers both apparent and implied authority, which is why these two types of authority are confused with each other by misunderstanding the qualifying features of each of them and not identifying the specific legal norms which establish them. Implied authority is established by Article 2.133(2) of the CC of the Republic of Lithuania, noting that the "rights of an agent may also arise from the circumstances under which an agent acts (salesperson in retail trade, cashier, etc.)". As stated before, this regulation is not fundamentally different from that which was enacted in 1964 under the CC of the Republic of Lithuania. When describing implied authority in the doctrine, in addition to the said provision, there is another relevant sentence in Article 2.133(2) of the CC of the Republic of Lithuania, establishing that "in the event that behaviour of a person gives reasonable grounds for the third persons to think that he has appointed the other person to be his agent, contracts concluded by the said person in principal's name shall be binding for the principal" (Aviža et al., 2009). As it is explained, this part of the legal rule is intended to describe apparent authority instead of implied authority. From the point of view of legal technique, it is to be criticized that the first sentence of Article 2.133(2) of the CC of the Republic of Lithuania defines implied authority, while the second defines apparent authority. For this reason, in the works of Lithuanian researchers, both implied and apparent authority were identified as the same up until 2011, and the country's case law is unable to draw a clear line between these two types of authority up until this day. Both the Court of Appeal of Lithuania (Judgment of the Court of Appeals of Lithuania of 2008 April 14, civil case no. 2A-471/2008) and the Supreme Court of Lithuania (SCL) (Judgment of the Supreme Court of Lithuania of 2011 April 12, civil case no. 3K-3-173/2011) have repeatedly noted that "pursuant to the provisions of Article 2.133(2), in the case of implied authority, in the event that behaviour of a 
person gives reasonable grounds for a third person to believe that he has appointed the other person to be his agent, contracts concluded by the said person in principal's name shall be binding for the principal, i.e. shall establish civil rights and obligations for him". Such merging of the concepts of apparent and implied authority shows that the courts do not identify apparent authority and implied authority as the basis for the establishment of two independent relationships of agency. That is why the courts are not always able to properly classify the factual circumstances of cases, as confirmed by specific case law.

In a case examined by the Kaunas Regional Court (Judgment of Kaunas Regional Court of Lithuania of 2008 April 14, civil case no. 2A-515-527/2008), there was a dispute due to the respondent's failure to make timely payments in accordance with the schedule for the repayment of advance payments. According to the respondent, she repaid part of her debt to the claimant's deputy director, as evidenced by the debt repayment letter signed by him. The claimant stated that the said money had not been added to the company's cash register, it must therefore be held that the respondent has failed to fulfil her obligations. The court relied on the doctrine of apparent authority and noted that the respondent could have reasonably assumed that the deputy director also had the right to accept debt repayment in cash, since it was customary in the company for the deputy director to travel to the company's divisions in performance of his duties, in order to perform cash acceptance and transfer operations. In this context, the court reduced the amount of the debt by the amount paid by the respondent. Although in the present case the court rightly acknowledged that the actions of the deputy director on behalf of the company have legal consequences for him, however, given the factual circumstances, it is more likely that the deputy director acted under the conditions of implied authority instead of apparent authority. More importantly, the claimant did not dispute whether the deputy director had the authority to accept money from third parties, but merely relied on the circumstance that the money paid by the respondent was not deposited to the company's cash register, which presupposes a dispute not as to the existence of the actual authority of the deputy director but as to the proper performance of his duties as the company's representative.

Other factual circumstances of the case examined by the Kaunas Regional Court (Judgment of Kaunas Regional Court of Lithuania of 2008 September 8, civil case no. 2A-824-601/2008) show that a resolution could also be made on the application of the rules of apparent and implied authority, although the court ruling does not specify these types of authority, nor does it refer to the legal rules regulating them (i.e., Article 2.132(2,9) of the CC of the Republic of Lithuania). In this case, the claimant sought payment of the debt under the sales contract of 2 January 2004. The respondent refused to cover it on the ground that the claimant had handed over the goods to a person unauthorized by the respondent. The respondent noted that the claimant had no reason to hand over the goods to T. S., who, although an employee of the respondent, was not appointed as his authorized agent for purchasing the goods. When resolving the dispute between the parties, the court formally stated, solely on the grounds of the employment contract, that this was not within the job duties of T. S. and that T. S. had no right to purchase and accept the goods from the claimant or sign the VAT invoices issued by the claimant on behalf of the respondent. The fact that this right of the agent was not expressly mentioned in the employment contract (it should be noted that the content of an employee's authority as an agent is usually not defined at all in the employment contract) does not mean that T. S. acted as an unauthorized person. The court did not assess whether, given the nature of the duties held by T. S. (supervisor), his actions could not be classified as having been performed with implied authority. The implied rights of T. S. could also be verified by the fact that it has been a common practice between the parties for many years for goods to be handed over to the respondent's employees without any authorization, and for the respondent to pay for such goods according to the issued VAT invoices. The transfer of the goods under this procedure lasted until 2006 and only then did the respondent declare that the goods must be transferred by the claimant to the respondent's employees who had approved authority to accept the goods. It is considered that these factual circumstances enable to establish a legal relationship of implied authority. On the other hand, even if the respondent was able to establish that T. S. acted without implied authority (for example, he was prohibited from carrying out the actions in question), the application of the doctrine of apparent authority could also be considered in the context of this dispute. The respondent's liability under the rules of apparent authority could be justified by the fact that the claimant (third party in the relationship of agency) had serious grounds to believe that T. S. was the respondent's duly authorized agent (this would be justified both by the practice between the parties and by the circumstance that the powers held by T. S. at the time of the transaction were verified by another employee of the respondent - J. M. G.) and that it was the respondent who was responsible for creating that impression.

The problem of delimitation of apparent and implied authority can also be seen in Civil Case No. 3K-3-393/2010 examined by the Supreme Court of Lithuania (Judgment of the Supreme Court of Lithuania of 2010 October 18, civil case no. 3K-3-393/2010). In this case, a dispute arose over the grant of the right to represent another shareholder at the general meeting of shareholders. G. V., one of the respondent's shareholders, issued a notarised power of attorney in Italian. During the general meeting of shareholders, the representative of shareholder G. V. was not allowed to vote, since a non-certified translated copy of the power of attorney was presented during the meeting instead of the original document. The SCL noted that "such failure to provide a power of attorney can only mean that there is no express authority and that this does not preclude the establishment of another type of authority - implied authority, in view of the factual circumstances". It is doubtful whether implied authority can be established in this case when 
the shareholder (principal) has clearly expressed his will for another person to represent him at the general meeting. The scope of the agent's authority is specifically defined and there is no need for a broad interpretation of the rights granted. It should however be noted that in certain cases the law may lay down requirements for the form of authority. Failure to comply with them will not produce the desired legal consequences of a transaction, despite the fact that the person has expressed his will. An analysis of foreign case law shows that in cases where the principal authorizes the agent without completing the necessary formalities, apparent authority is applied (Beale et al., 2010). It should also be noted that the discussed SCL case is non-standard in the sense that in this case the third party relied on the absence of form requirements, even though usually it is the principal who tends to abuse this circumstance.

A dispute of a rather similar nature was also examined by the SCL in Civil Case No. 3K-3-1057/2003 (Judgment of the Supreme Court of Lithuania of 2003 November 5, civil case no. 3K-3-1057/2003). The claimant, a shareholder, applied to the court for annulment of the resolution of the general meeting of shareholders on the grounds that the meeting had been convened without informing him thereof. The respondent, the company whose shareholders' resolution was being challenged, stated that the claimant had been represented at the meeting by a third party, A. V., who had acted on the basis of a power of attorney issued by the shareholder. The claimant was also notified through A. V. of the convening of the meeting. Although the power of attorney issued by the claimant did not state that the agent is authorized to receive information about the convened general meetings of shareholders, it is considered that this right is inseparable from the agent's mandate. The existence of the legal relationship of implied authority is also supported by other factual circumstances. As established by the courts examining the case, the claimant did not participate in the general meetings of shareholders for more than two years in any way other than through its agent A.V. In addition, the practice of convening meetings was such that the agent in Lithuania of the claimant - foreign company - was informed thereof. It can be accepted that, due to the existence of such a long-standing practice, which has never been disputed by the claimant as infringing its right to know about the convening of a meeting and to take part in the said meeting, there is no reason to state that this was unauthorized agency.

In another civil case, the court established that a person acted with implied authority, although factual circumstances are presumed to have led to a decision on the application of the rules of apparent authority. In its judgement passed in Civil Case No. 3K-3-147/2007 (Judgment of the Supreme Court of Lithuania of 2007 April 6, civil case no. 3K-3-147/2007), the SCL noted that "an agent may be authorized by the issuance of a written power of attorney (Article 2.137 of the CC), or the rights of an agent may also arise from the circumstances under which an agent acts (Article 2.133(2) of the CC)". The SCL found that the contract according to which the claimant provided consultations to the respondent regarding the company's activities was signed by the respondent's administrator V. A., who was later appointed to be the director of the company. Despite this fact, the court established that this contract has legal consequences, since V. A. actually managed all the company's activities and concluded the company's contracts using not only the company's seal, but also the signature seal of the company's owner. According to the SCL's interpretation, V. A. had implied authority to enter into contracts with third parties on behalf of the respondent. The result of this decision is unquestionable, but in view of the fact that $\mathrm{V}$. A. was not the director of the company at the time of the dispute, i.e., she was not authorized to enter into contracts on behalf of the company, it can be assumed that V. A. acted as an apparent agent. As seen from the facts of the case, the claimant had reason to believe that he was concluding a contract with a duly authorized agent of the company, a belief which was prompted by the circumstances of the agent's behaviour (to whom the company's seal and signature seal of the company's owner were given, who was enabled to manage all the company's activities, etc.).

The doctrine of apparent authority instead of implied authority should have probably been relied on in Civil Case No. 3K-3-173/2011 examined by the SCL (Judgment of the Supreme Court of Lithuania of 2011 April 12, civil case No. 3K-3-173/2011). In this case, a dispute arose as to whether the respondent (vehicle lessor) was required to reimburse the claimant (vehicle lessee) for the costs of repairing and transporting the vehicle. The claimant based this claim on agreements signed by the respondent's employee (deputy technical director), under which the respondent undertook to pay for the repair of the vehicle and to reimburse the costs incurred by the claimant. In turn, the respondent indicated that the employee was only authorized to hand over the vehicle, but was not entitled to negotiate reimbursement of the said costs. While examining this dispute, the court ruled that Article 2.133(2) of the CC of the Republic of Lithuania establishes implied authority, which, as mentioned before, is not entirely accurate. Part 9 of the same article was also invoked in the course of the proceedings, by no longer linking it to implied authority, but also not specifying that this legal rule regulates apparent authority. Despite the inaccurately used terminology, it is considered that the SCL properly qualified the relationship of the dispute, which is confirmed by specific circumstances. The courts of lower instance have found that agreements signed between the respondent's employee and the claimant for the reimbursement of vehicle repair costs cannot be construed as an amendment to the vehicle rental agreement, and they did not impose any obligations on the parties under this agreement, since the respondent's employee did not have the authority to enter into the dispute agreements. The SCL does not question this conclusion, i.e., does not deny the fact that, in the case of the dispute, a legal relationship of unauthorized agency was established, but emphasizes that the courts examining the case did not assess the circumstances specified in Article 2.133(2,9) of the CC of the Republic of Lithuania. After the respondent declared that he does not approve contracts, it was necessary to take into 
account the arguments of the claimant that he reasonably believed that the respondent's employee was acting on his behalf as a duly authorized agent, and did not know and did not have to know that he was exceeding his authority. In other words, the courts did not consider whether, in this case, the interests of the claimant as a third party in the relationship of agency could be protected under the rules on apparent authority. That is why the case was remanded to the Court of Appeal for further proceedings.

In another case (Judgment of the Supreme Court of Lithuania of 2010 February 8, civil case no. 3K-3-38/2010), the SCL properly qualified the dispute as implied authority, but unnecessarily analysed whether the third party had serious grounds to believe that it was concluding a contract with an agent who had the right to do so. This circumstance, as will be explained later, is a prerequisite for the application of the doctrine of apparent authority, however it is irrelevant in determining whether the agent acted with implied authority. Such inaccuracy was probably caused by the fact that the courts examining the case linked implied authority with the entire Article 2.133(2) of the CC of the Republic of Lithuania, which, as mentioned before, also regulates apparent authority (Judgment of the Court of Appeals of Lithuania of 2008 September 15, civil case no. 2A-471/2008). The existence of an implied authority relationship between the parties to the dispute is confirmed by the fact that the respondent had drawn up a performance and order allocation scheme, according to which his agent, who worked as an accountant, searched for work objects, distributed work tasks among employees, took them to the object, and made agreements with customers regarding the relevant work. Given the above, it may be presumed that the person was in fact entitled to act on behalf and in the interests of the respondent carrying out the roofing, repair and construction work. In addition, these works were carried out with the knowledge and control of the company's management and owners.

It should be noted that recent case law has drawn a clearer distinction between apparent and implied authority, at least in terms of concept (Judgment of the Supreme Court of Lithuania of 2012 March 20, civil case no. 3K-3102/2012, Judgment of the Supreme Court of Lithuania of 2017 November 11, civil case no. e3K-3-394-684/2017, Judgment of the Supreme Court of Lithuania of 2019 December 17, civil case no. e3K-3-381-684/2019, Judgment of the Supreme Court of Lithuania of 2021 February 25, civil case no. e3K-3-11-701/2021). Although apparent authority continues to be interpreted exclusively in the context of Article 2.133(9) of the CC of the Republic of Lithuania, implied authority is no longer linked to the entire part 2 of the same article. It should be noted that the "scope of the rights conferred on an agent, as well as the fact of agency itself may also arise from specific circumstances under which an agent acts (salesperson in retail trade, cashier, etc.) (Article 2.133(2) of the CC)". Hopefully this interpretation of the SCL and the recent detailed analysis of apparent and implied authority in the doctrine of Lithuanian law (Tikniūté, 2011; Pakalniškis \& Jurkevičius, 2011) will lead to the formation of a more accurate and uniform practice of Lithuanian courts in interpreting these specific legal relationships of agency.

\section{Conclusions}

Apparent authority is mainly the result of the conclusions of case law and the legal doctrine. This institute is interpreted differently in different legal systems on the basis of certain more general theories and principles of private law. For example, in England and other common law countries, apparent authority is based on the rule of estoppel, in France and Belgium - on the theory of false belief, in the Netherlands and PECL - on the principle of protection of legitimate expectations, in Germany - on the doctrine of culpa in contrahendo, in the principles of UNIDROIT - on provisions of fairness and prohibition of inconsistent behaviour.

In a general sense, apparent authority can be described as cases where the principal has not authorized the agent or granted limited rights to the agent to act on his behalf, however, due to the behaviour of the principal or other circumstances related thereto, the third party reasonably and honestly believes that the agent has been duly authorized. Apparent authority is only an illusion of agency that becomes a reality through law.

It is important to distinguish apparent authority from other types of authority, especially implied authority. Implied authority arises from factual circumstances under which the agent acts and must be regarded as part of actual authority, which presupposes that, unlike in the case of apparent authority, the actions performed by the agent do not mean that the agent exceeds his authority.

Given that apparent authority and implied authority are not clearly demarcated in the Civil Code of the Republic of Lithuania, it is proposed to revise Article 2.133(9) of this legal act by providing that, if the principal's behaviour has given serious grounds for the third party to believe that he concluded a contract with a duly authorized agent, or if such belief of the third party is determined by other circumstances related to the principal, the contract should be binding on the principal, unless the counterparty knew or should have known that the agent exceeded his rights or was not granted such rights at all.

\section{Disclosure statement}

Authors declare that they do not have any competing financial, professional, or personal interests from other parties. 


\section{References}

Aviža, S., Mikelėnas, V., Staskonis, V., Bosaitè, A., Butov, S., Brazdeikis, A., Mizaras, V., Juzikienė, R, \& Smaliukas, A. (2009). Civiline teisé. Bendroji dalis. Justitia.

Beale, H., Fauvarque-Cosson, B., Rutgers, J., Tallon, D., \& Vogenauer, S. (2010). Cases, materials and text on contract law. Hart Publishing. https://research.vu.nl/en/publications/cases-materials-and-text-on-contract-law

Beatson, J. (2002). Anson's Law of Contract (28 ${ }^{\text {th }}$ ed.). Oxford University Press. https://www.euppublishing.com/doi/abs/10.3366/ elr.2003.7.2.257

Boons, F., \& Lüdeke-Freund, F. (2013). Business models for sustainable innovation: State-of-the-art and steps towards a research agenda. Journal of Cleaner Production, 45, 9-19. https://doi.org/10.1016/j.jclepro.2012.07.007

Busch, D. (2009). Unauthorised agency in Dutch law. In D. Busch \& L. J. Macgregor (Eds.), The unauthorised agent: Perspectives from European and Comparative Law (pp. 136-182). Cambridge University Press. https://doi.org/10.1017/CBO9780511575914.007

Busch, D., \& Macgregor, L. (2007). Apparent authority in Scots Law: Some international perspectives. Edinburgh Law Review, 11(3), 349-378. https://doi.org/10.3366/elr.2007.11.3.349

Busch, D., \& Macgregor, L. J. (2009). Comparative law evaluation. In D. Busch \& L. J. Macgregor (Eds.), The unauthorised agent: Perspectives from European and Comparative Law (pp. 385-438). Cambridge University Press. https://doi.org/10.1017/CBO9780511575914

DeMott, D. A. (2006). Breach of fiduciary duty: On justifiable expectations of loyalty and their consequences. Arizona Law Review, 48, 925-956. https://papers.ssrn.com/sol3/papers.cfm?abstract_id=924776

Dyllick, T., \& Muff, K. (2016). Clarifying the meaning of sustainable business: Introducing a typology from business-as-usual to true business sustainability. Organization \& Environment, 29(2), 156-174. https://doi.org/10.1177/1086026615575176

Elliott, C., \& Quinn, F. (2005). Contract Law. Longman.

International Institute for the Unification of Private Law. (1983). Geneva Convention on agency in the international sale of goods. https://www.unidroit.org/ol-agency/ol-agency-en

International Institute for the Unification of Private Law. (2016). UNIDROIT principles of international commercial contracts. https://www.unidroit.org/instruments/commercial-contracts/unidroit-principles-2016

Judgment of Kaunas Regional Court of Lithuania of 2008 April 14, civil case no. 2A-515-527/2008.

Judgment of Kaunas Regional Court of Lithuania of 2008 September 8, civil case no. 2A-824-601/2008.

Judgment of the Court of Appeals of Lithuania of 2008 April 14, civil case no. 2A-471/2008.

Judgment of the Court of Appeals of Lithuania of 2008 September 15, civil case no. 2A-471/2008.

Judgment of the Supreme Court of Lithuania of 2003 November 5, civil case no. 3K-3-1057/2003.

Judgment of the Supreme Court of Lithuania of 2007 April 6, civil case no. 3K-3-147/2007.

Judgment of the Supreme Court of Lithuania of 2010 February 8, civil case no. 3K-3-38/2010.

Judgment of the Supreme Court of Lithuania of 2010 October 18, civil case no. 3K-3-393/2010.

Judgment of the Supreme Court of Lithuania of 2011 April 12, civil case no. 3K-3-173/2011.

Judgment of the Supreme Court of Lithuania of 2012 March 20, civil case no. 3K-3-102/2012.

Judgment of the Supreme Court of Lithuania of 2017 November 11, civil case no. e3K-3-394-684/2017.

Judgment of the Supreme Court of Lithuania of 2019 December 17, civil case no. e3K-3-381-684/2019.

Judgment of the Supreme Court of Lithuania of 2021 February 25, civil case no. e3K-3-11-701/2021.

Jurkevičius, V., \& Bublienė, R. (2017). Towards sustainable business relationships: ratification doctrine in the case of unauthorised agency. Entrepreneurship and Sustainability Issues, 5(1), 72-90. https://doi.org/10.9770/jesi.2017.5.1(6)

Jurkevičius, V., \& Pokhodun, Y. (2018). The doctrine of apparent authority as a precondition for sustainable business. Entrepreneurship and Sustainability Issues, 6(2), 649-661. https://doi.org/10.9770/jesi.2018.6.2(13)

Kotz, H., \& Flessner, A. (1997). European Contract Law. Vol. 1: Formation, validity, and content of contracts; contract and third parties. Clarendon Press. http://www.sudoc.abes.fr/cbs/DB=2.1//SRCH?IKT=12\&TRM=046114386\&COOKIE=U10178,Klecteurweb,D2.1,E97c9062f-63,I250,B341720009+,SY,QDEF,A\%5C9008+1,,J,H2-26,,29,,34,,39,,44,,49-50,,53-78,,80-87,NLECTEUR+PSI,R84.240.59.44,FN

Lando, O., \& Beale, H. (Eds.). (2000). Principles of European Contract Law. Parts I and II (Combined and Revised). Kluwer Law International, The Hague. https://academic.oup.com/ulr/article-abstract/5/3/624/1653037

Levinthal, I. H. (1923). The Jewish law of agency: With special reference to the Roman and Common law. Conat Press. https:// books.google.lt/books/about/The_Jewish_Law_of_Agency.html?id=EHsrAAAAIAAJ\&redir_esc=y

Lietuvos Respublikos Seimas. (2000). Lietuvos Respublikos civilinio kodekso patvirtinimo, isigaliojimo ir igyvendinimo įstatymas. 2000 m. liepos 18 d. Nr. VIII-1864. [Civil Code of the Republic of Lithuania]. https://e-seimas.lrs.lt/portal/legalAct/lt/TAD/ TAIS. 107687

Meier, L. (2007). Using agency law to determine the boundaries of the free speech and establishment clauses. Indiana Law Review, 40(3), 519-528. https://heinonline.org/HOL/AuthorProfile?base=js\&search_name=Meier,\%20D.\%20Luke\&1==1616683074

Munday, R. (2010). Agency law and principles ( $1^{\text {st }}$ ed.). Oxford University Press. https://www.amazon.com/Agency-Law-Principles-Roderick-Munday/dp/0199230374

Pakalniškis, V., \& Jurkevičius, V. (2011). Tariamas atstovavimas pozityviojoje teisèje ir teismų praktikoje. Jurisprudencija, 18(4), 1443-1466. https://www.researchgate.net/publication/299398369_Tariamas_atstovavimas_pozityviojoje_teiseje_ir_teismu_ praktikoje

Reynolds, F. M. B., Watts, P., \& Bowstead, W. (2010). Bowstead and Reynolds on agency. Sweet \& Maxwell Ltd. https://www. worldcat.org/title/bowstead-and-reynolds-on-agency/oclc/632086297 
V. Jurkevičius, R. Bubliene. 2021. Interaction between apparent and implied authority

in the implementation of sustainable business relatiohsips

Saintier, S. (2009). Unauthorised Agency in French law. In D. Busch \& L. J. Macgregor (Eds.), The unauthorised agent: Perspectives from European and Comparative Law (pp. 17-60). Cambridge University Press. https://doi.org/10.1017/CBO9780511575914.004

Samoy, I. (2009). Unauthorised Agency in Belgian law. In D. Busch \& L. J. Macgregor (Eds.), The unauthorised agent: Perspectives from European and Comparative Law (pp. 61-99). Cambridge University Press. https://doi.org/10.1017/CBO9780511575914.005

Schmidt-Kessel, M., \& Baide, A. (2009). Unauthorised Agency in German law. In D. Busch \& L. J. Macgregor (Eds.), The unauthorised agent: Perspectives from European and Comparative Law (pp. 100-135). Cambridge University Press. https://doi.org/10.1017/CBO9780511575914.006

Seavey, W. A. (1964). Handbook on the Law of Agency. West.

Smits, J. M. (2007). Elgar encyclopedia of comparative law. The Berkeley Economic Press. https://doi.org/10.4337/9781847200204

Stoljar, S. J. (1961). The Law of Agency: Its history and present principles. Sweet \& Maxwell.

Tikniūtè, A. (2011). Atstovo igaliojimų viršijimas - teorija ir praktika. Jurisprudencija, 18(3), 979-994. https://www3.mruni.eu/ ojs/jurisprudence/article/view/587

Verhagen, H. L. E. (1995). Agency in Private International Law: The Hague convention on the law applicable to agency. Martinus Nijhoff Publishers / Asser Instituut. https://www.hcch.net/en/publications-and-studies/details4/?pid=843

Vogenauer, S., \& Kleinheisterkamp, J. (2009). Commentary on the UNIDROIT Principles of International Commercial Contracts (PICC). Oxford University Press. http://eprints.lse.ac.uk/23710/

Von Bar, C., Clive, E., \& Schulte-Nölke, H. (Eds.). (2009). Principles, definitions and model rules of European Private Law. Draft Common Frame of Reference (DCFR). Full Edition. Vol. I. Otto Schmidt / De Gruyter European Law Publishers. https://doi.org/10.1515/9783866537279

Zimmermann, R. (2009). The unauthorized agent: Where do we stand today? An introduction to the symposium. European Review of Private Law, 17(6), 961-966. 